\title{
PERLINDUNGAN HUKUM HAK KEKAYAAN INTELEKTUAL MELALUI MEKANISME “CROSS BORDER MEASURE"
}

\author{
Yoga Mahardhita; Ahmad Yakub Sukro \\ Magister Ilmu Hukum Universitas Diponegoro \\ Semarang yoga.mahardhita@gmail.com; \\ yakub.sukro@gmail.com
}

\begin{abstract}
Abstrak
Perlindungan hukum Hak Kekayaan Intelektual (HKI) di Kawasan Pabean (Cross Border Measure) memiliki posisi yang sangat strategis. Hal tersebut dikarenakan ruang lingkupnya yang berada dalam jalur lalu lintas perdagangan internasional, baik sebelum barang-barang hasil bajakan atau pemalsuan beredar ke pasar nasional atau sebelum barang tersebut diekspor ke luar wilayah Indonesia. Seiring dengan meningkatnya kejahatan pemalsuan dan pembajakan internasional yang berdampak pada hilangnya potensi penerimaan negara, menurunnya inovasi sampai dengan sanksi internasional, telah mendorong Pemerintah untuk meningkatkan pengawasan barang yang terkait dengan HKI di wilayah perbatasan melalui penguatan kerangka hukum maupun operasional sesuai dengan Trade Related Aspects of Intellectual Property Rights (TRIPs Agreement).Penelitian ini bertujuan untuk mengetahui mekanisme perlindungan hukum di wilayah Kawasan Pabean dalam kerangka Cross Border Measure yang dilakukan oleh otoritas kepabeanan (Direktorat Jenderal Bea dan Cukai). Metode penelitian dilakukan dengan pendekatan yuridis normatif, dimana penelitian dilakukan dengan mengacu pada peraturan perundang-undangan yang berkaitan dengan permasalahan yang dibahas dengan cara meneliti bahan pustaka atau data sekunder. Hasil penelitian menunjukkan bahwa perlindungan hukum HKI melalui mekanisme Cross Border Measure dapat dilakukan melalui 2 (dua) cara, yaitu melalui penetapan secara jabatan (ex-officio) oleh DJBC dan melalui perintah oleh Pengadilan Niaga (yudisial). Meskipun telah diterbitkan Peraturan Pemerintah Nomor 20 Tahun 2017 tentang Pengendalian Impor Atau Ekspor Barang Yang Diduga Merupakan Atau Berasal Dari Hasil Pelanggaran Hak Kekayaan Intelektual, namun masih diperlukan adanya aturan pelaksanaan yang mengatur secara teknis pelaksanaan Peraturan Pemerintah tersebut, seperti tata laksana perekaman (recordation system) bagi pemegang hak atau pemilik hak untuk memperoleh perlindungan HKI secara ex-officio.
\end{abstract}

Kata kunci : perlindungan hukum, hukum kekayaan intelektual, Cross Border Measure. 


\section{A. Pendahuluan}

Perdagangan internasional melalui impor dan ekspor semakin lama menjadi semakin pesat perkembangannya seiring dengan bertambahnya penduduk dunia dan semakin beragamnya kebutuhan manusia. Kemajuan teknologi informasi dan transportasi turut mendorong peningkatan volume perdagangan dan pemasaran suatu produk yang tidak hanya bersifat lokal akan tetapi melewati batas-batas negara.

Saat ini, perdagangan internasional tidak hanya terbatas pada perdagangan barang, tetapi juga mencakup perdagangan jasa dan kekayaan intelektual (intellectual property). Pertukaran informasi, ide, modal, dan teknologi baru telah menjadi bagian dari kehidupan sehari-hari masyarakat dunia. Dampak globalisasi ekonomi yang ditandai dengan adanya gerakan perdagangan dan pesaingan bebas, peningkatan skala investasi dan pemasaran produk, mengakibatkan semakin terasanya kebutuhan perlindungan terhadap hak kekayaan intelektual yang sifatnya tidak lagi timbal balik, tetapi sudah bersifat antarnegara secara global. ${ }^{1}$

Sebagaimana proses timbulnya pelanggaran pada umumnya yang tumbuh dan berkembang di tengah masyarakat, terjadinya peredaran barang palsu (counterfeiting) dan hasil bajakan (piracy) dipengaruhi oleh beberapa aspek: ${ }^{2}$

1. Aspek Ekonomi, pada umumnya harga produk-produk ilegal yang beredar di pasaran lebih murah dibandingkan dengan produk yang legal atau asli, sehingga konsumen glongan menengah ke bawah cenderung memilih produk yang lebih murah apabila kualitas tidak jauh berbeda.

2. Aspek Sosial, pengaruh globalisasi secara umum telah mendorong pengusaha untuk memacu hasil industrinya yang sekaligus memicu persaingan curang. Tingginya angka pengangguran juga mendorong sebagian masyarakat untuk

\footnotetext{
${ }^{1}$ Muhamad Djumhana dan R. Djubaedillah, Hak Milik Intelektual (sejarah, teori dan praktiknya di Indonesia), (Bandung: PT. Citra Aditya Bakti, 2014), hal. 7

${ }^{2}$ Cita Citrawinda Priapantja, Hak Kekayaan Intelektual Tantangan Masa Depan, Cet. 1, (Jakarta: Badan Penerbit Fakultas Hukum Universitas Indonesia, 2003), hal. 166-168. Lihat juga dalam Adrian Sutedi, Aspek Hukum Kepabeanan Indonesia, (Jakarta: Sinar Grafika, 2012) hal. 312-313
} 
melakukan pekerjaan apa saja, termasuk yang berkaitan dengan pelanggaran HKI, misalnya pedagang kaki limavideo compact disc(VCD) bajakan.

3. Aspek Budaya, adanya budaya kebersamaan masyarakat Indonesia yang bercirikan patembayan dapat menimbulkan perbedaan persepsi tentang makna HKI yang cenderung individual sehingga menghambat sosialisasi pelaksanaan HKI. Selain itu, adanya kecenderungan 'Brand Minded' bagi sebagian masyarakat yang berpengaruh pada 'prestise' seseorang, dapat mendorong adanya penggunaan merek palsu.

Berdasarkan data yang diperoleh oleh Kementerian Perindustrian melalui masukan dari Masyarakat Indonesia Anti Pemalsuan (MIAP), diperkirakan kerugian terhadap beredarnya barang-barang dan produk palsu mencapai nilai $\mathrm{Rp}$. 65 triliun. Kerugian terdiri dari produk makanan dan minuman Rp 13,39 triliun, produk pakaian dan barang dari kulit Rp 41,58 triliun, produk obat-obatan dan kosmetik Rp 6,5 triliun serta produk software dan tinta $\mathrm{Rp} \mathrm{3,6} \mathrm{triliun.}{ }^{3}$ Data dari Organization of Economic Cooperation and Development (OECD) juga mencatat bahwa kerugian yang ditimbulkan akibat adanya pelanggaran HKI selalu mengalami kenaikan setiap tahunnya, dengan perkiraan pada tahun 2013 mencapai $2.5 \%$ dari total nilai perdagangan dunia atau setara dengan 461 juta US dollar. ${ }^{4}$

Selain dari sisi ekonomi, kerugian pemalsuan suatu produk juga mengancam kesehatan dan keselamatan bagi masyarakat, misalnya adanya obat palsu yang menyebabkan gangguan kesehatan hingga kematian bagi penggunanya, baterai palsu yang memiliki kecenderungan untuk mudah meledak, suku cadang kendaraan bermotor palsu yang memiliki kualitas rendah memiliki kontribusi yang besar pada kerusakan mesin dan bahkan kecelakaan lalu lintas. ${ }^{5}$

\footnotetext{
${ }^{3}$ Data dari Kementerian Perindustrian melalui http://kemenperin.go.id/artikel/9703/KerugianAkibat-Peredaran-Barang-Palsu-Capai-Rp-65-T, diakses tanggal 5 Februari 2018

${ }^{4}$ Organization of Economic Cooperation and Development, Trade in Counterfeit and Pirated Goods: Mapping the Economic Impact, (Paris: OECD Publishing, 2016) hal. 11, diakses melalui http://dx.doi.org/10.1787/9789264252653-en, tanggal 20 Januari 2018

${ }^{5}$ Warta Bea Cukai, Volume 47 Nomor 8, Agustus 2015, halaman 28-29, diakses melalui https://www.scribd.com/document/341683150/Warta-BC-8-Agustus, tanggal 2 Januari 2018
} 
Upaya-upaya untuk melaksanakan perlindungan hak kekayaan intelektual yang memadai (adequate intellectual property right protection) dalam beberapa tahun terakhirdirasakan semakin meningkat, baik di tingkat regional maupun internasional. Dalam tatanan internasional sejak disepakatinya perjanjian internasional tentang aspek-aspek hak kekayaan intelektual dalam perdagangan Trade Related Aspects of Intellectual Property Rights (TRIPs Agreement), yang merupakan bagian tidak terpisahkan dari perjanjian tentang pendirian World Trade Organization (WTO), telah diratifikasi oleh 150 lebih negara di dunia. Perjanjian ini mengukuhkan penegakan hukum (law enforcement) yang lebih ketat dan memperluas ruang lingkup perlindungan Hak Kekayaan Intelektual dari perjanjian internasional sebelumnya yang diprakarsai oleh World Intellectual Property Organization (WIPO), seperti Bern Convention, Paris Convention, Rome Convention dan Washington Treaty. ${ }^{6}$

Perlindungan hukum HKI dalam skema border measure di dalam the TRIPs Agreement termuat dalam Article 51 sampai dengan Article 60 yang memerintahkan pelaksanaan penangguhan pengeluaran barang oleh otoritas kepabeanan terhadap barang yang diduga terkait dengan pelanggaran HKI (suspension of release by Customs Authorities). Sebagai wujud komitmen keikutsertaan Indonesia dalam penandatanganan pembentukan organisasi perdagangan dunia (World Trade Organization), ketentuan border measurekemudian diadopsi dalam Pasal 54 sampai dengan Pasal 64 Undangundang Nomor 10 Tahun 1995 tentang Kepabeanan sebagaimana telah diubah dengan Undang-Undang Nomor 17 tahun 2006 (UU Kepabeanan). Meskipun ketentuan penangguhan oleh pihak kepabeanan (Direktorat Jenderal Bea dan Cukai) telah diatur sejak diterbitkannya UU Kepabeanan, namun peraturan pelaksanaanya baru diterbitkan dan diundangkan 22 Tahun setelahnya, tepatnya pada tanggal 2 Juni 2017. Selama kurun waktu tersebut, dalam rangka mengisi kekosongan aturan pelaksanaan, Mahkamah Agung telah menetapkan Peraturan ${ }^{6}$ Kholis Roisah, Konsep Hukum Hak Kekayaan Intelektual: sejarah, pengertian dan filosofi
pengakuan HKI dari masa ke masa, (Malang: Setara Press, 2015), halaman 3 
Mahkamah Agung Nomor 4 Tahun 2012 tentang Perintah Penangguhan Sementara.

Apabila ditinjau dari ketentuan penegakan HKI melalui crossborder measure, maka tindakan Pejabat Bea dan Cukai sangat terbatas hanya sepanjang penangguhan pengeluaran barang, namun tindakan ini dianggap cukup efektif untuk pencegahan tindak pelanggaran HKI. Tindakan penangguhan yang dilaksanakan pada exit atau entry point di dalam Kawasan Pabean dapat mencegah barang-barang yang diduga terindikasi pelanggaran Hak Kekayaan Intelektual, sebelum barang tersebut masuk ke dalam distribusi komersial di pasaran masyarakat, dimana pencegahannya akan lebih rumit, sangat kompleks dan membutuhkan dana yang tidak sedikit.

\section{B. Metode Penelitian}

Penelitian merupakan sarana yang dipergunakan oleh manusia untuk memperkuat, membina serta mengembangkan ilmu pengetahuan. Ilmu pengetahuan yang merupakan pengetahuan yang tersusun secara sistematis dengan penggunaan kekuatan pemikiran, pengetahuan yang mana senantiasa dapat diperiksa dan ditelaah secara kritis, akan berkembang terus atas dasar penelitianpenelitian yang diadakan pendahulunya. Hal itu terutama disebabkan penggunaan ilmu pengetahuan bertujuan agar manusia lebih mengetahui dan lebih mendalami. $^{7}$

Penelitian ini menggunakan metode pendekatan yuridis normatif yang berarti bahwa penelitian ini mengacu pada peraturan perundang-undangan yang berkaitan dengan permasalahan yang dibahas dengan cara meneliti bahan pustaka atau data sekunder dengan inventarisasi hukum positif. Bahan hukum primer yang digunakan dalam penelitian ini yaitu Undang-Undang Nomor 10 Tahun 1995 tentang Kepabeanan sebagaimana telah diubah dengan Undang-Undang Nomor 17 Tahun 2006 dan Peraturan Pemerintah Nomor 20 Tahun 2017 tentang Pengendalian Impor Atau Ekspor Barang Yang Diduga Merupakan Atau Berasal Dari Hasil Pelanggaran Hak Kekayaan Intelektual. Sedangkan bahan hukum

${ }^{7}$ Soerjono Soekanto, Pengantar Penelitian Hukum (Jakarta: UI-Press, 2010), hal. 3. 
sekunder dapat bersumber dari buku-buku, tesis maupun jurnal yang berkaitan dengan permasalahan.

\section{Hasil Penelitian dan Pembahasan}

\section{Arti PentingPerlindungan Hukum HKI}

Hak kekayaan intelektualatau yang biasa disingkat dengan "HKI" atau akronim "HaKI", adalah padanan kata yang biasa digunakan untuk Intellectual Property Rights (IPR), yakni hak yang timbul bagi hasil olah pikir yang menghasikan suatu produk atau proses yang berguna untuk manusia yang pada intinya HKI adalah hak untuk menikmati secara ekonomis hasil dari suatu kreativitas intelektual. Objek yang diatur dalam HKI adalah karya-karya yang timbul atau lahir karena kemampuan intelektual manusia. ${ }^{8}$

Menurut Budi Santoso, Hak Kekayaan Intelektual diartikan sebagai suatu hak yang timbul sebagai hasil kemampuan intelektual manusia dalam berbagai bidang yang menghasilkan suatu proses atau produk bermanfaat bagi manusia. Hak kekayaan intelektual memiliki dua aspek utama, pertama yaitu proses dan produk meliputi berbagai bidang secara luas, mulai dari bidang seni dan sastra hingga invensi dan inovasi di bidang teknologi serta segala bentuk lainnya yang merupakan hasil dari proses kreativitas manusia lewat cipta, rasa, dan karsanya. Kedua, karya cipta atau invensi tersebut menimbulkan hak milik bagi pencipta dan penemunya. Sifatnya sebagai hak milik, maka karenanya hak seorang pencipta atau penemu atas karya ciptanya haruslah dilindungi. ${ }^{9}$

Perlindungan terhadap HKI pada dasarnya berintikan pengakuan atas kekayaan tersebut dan hak untuk jangka waktu tertentu menikamti atau mengeksploitasi sendiri kekayaan tadi. Selama kurun waktu tertentu itu orang lain tidak dapat menikmati ataupun menggunakan, atau mengeksploitasi hak tersebut tanpa ijinnya. ${ }^{10}$ HKI bersifat eksklusif dan mutlak, artinya bahwa HKI dapat

\footnotetext{
${ }^{8}$ Direktorat Jenderal Hak Kekayaan Intelektual Kementerian Hukum dan HAM RI, Buku Panduan Hak Kekayaan Intelektual 2013, (Tangerang: 2013), halaman iii

${ }^{9}$ Budi Santoso, Pengantar Hak Kekayaan Intelektual, (Semarang: Pustaka Magister, 2008), halaman 3

${ }^{10}$ Bambang Kesowo, Posisi dan Arti Penting HKI Dalam Perdagangan Internasional, (Jakarta:1993)
} 
dipertahankan terhadap siapapun dan yang mempunyai hak dapat menuntut terhadap pelanggaran yang dilakukan oleh siapapun. Pemegang HKI juga mempunyai hak monopoli, yaitu hak yang dapat dipergunakan dengan melarang siapapun tanpa persetujuannya membuat ciptaan/penemuannya ataupun menggunakannya.

Konsep kepemilikan HKI lahir dari pemikiran John Locke, filsuf Inggris abad ke-16 tentang pemikiran hak milik. Menurut Locke, hak milik adalah satu dari tiga hal yang tidak dapat dipisahkan dari manusia. Manusia lahir 'tabula rasa' artinya dalam keadaan bebas dan setara di bawah hokum kodrat. Hukum kodrat melarang siapapun merusak, menghilangkan kehidupan, kebebasan, serta hak milik.Ketiga hal tersebut menurut Locke tidak dapat dilepaskan dari diri manusia karena datangnya dari Yang Maha Kuasa. Setiap manusia memiliki dirinya sendiri sebagai miliknya dan tidak ada seorangpun memiliki hak atas pribadi orang lain kecuali pemiliknya sendiri, termasuk hasil kerja tubuhnya dan karya tangannya serta panca inderanya. Artinya setiap orang secara alamiah mempunyai hak untuk memiliki segala potensi yang melekat pada diri pribadinya dan seluruh kerja yang dihasilkannya. $^{11}$

Perlindungan hukum terhadap pemilik HKI diperlukan agar pemilik hak dapat menggunakan atau mengeksploitasi kekayaannya dengan rasa aman. Pada gilirannya rasa aman itulah kemudian menciptakan iklim atau suasana yang memungkinkan orang dapat berkarya guna menghasilkan karya atau temuantemuan berikutnya. Sebaliknya dengan perlindungan hukum itu pula pemilik hak dapat diminta untuk mengungkapkan bentuk, jenis dan cara kerja serta manfaat daripada kekayaannya dengan cara aman karena ada jaminan hukum dan bagi masyarakat dapat menikmati atau menggunakan atas dasar ijin, atau bahkan untuk mengembangkannya. ${ }^{12}$

Perlindungan terhadap HKI terkandung hak individu dan hak masyarakat. Hak individu yang tercermin sebagai hak eksklusif sang pemegang HKI dan hak masyarakat untuk memperoleh dan mengakses kekayaan intelektual, sehingga

\footnotetext{
${ }^{11}$ Kholis Roisah, Op. Cit., hal. 13-14

${ }^{12}$ Sunaryati Hartono, Hukum Ekonomi Pembangunan Indonesia, Cetakan Pertama, (Bandung: Bina Cipta, 1982), hal. 7
} 
diperlukan suatu prinsip yang bertujuan menyeimbangkan antara kepentingan sang individu pemilik hak dan kepentingan masyarakat. Dalam rangka menyeimbangkan kepentingan individu pemegang HKI dengan kepentingan masyarakat, maka suatu sistem perlindungan HKI harus berdasarkan prinsipprinsip yang dapat digambarkan sebagai berikut:

\section{Gambar 1}

Prinsip-prinsip Dasar Perlindungan Kekayaan Intelektual ${ }^{13}$

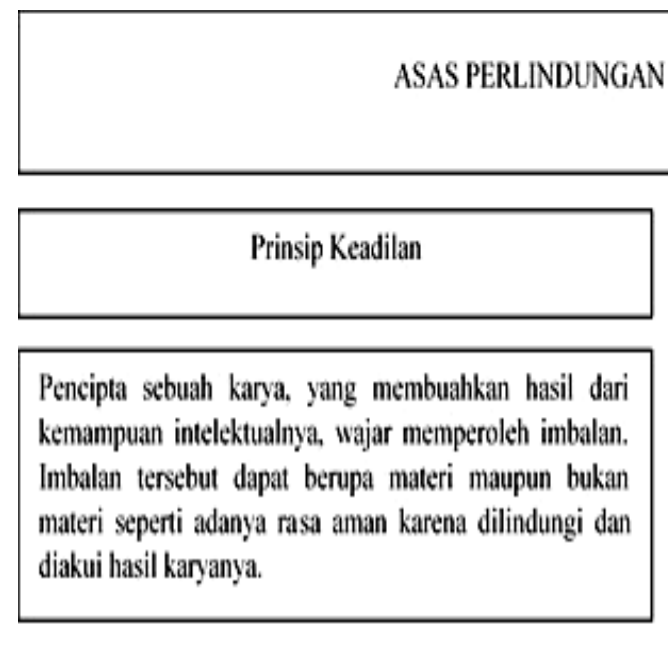

Prinsip Kebudayaan

Pengakuan atas karya, karsa, cipta manusia sebagai perwujudan suasana yang mampu membangkitkan semangat dan minat untuk mendorong ciptaan atau penemuan baru yang berguna bagi peningkatan taraf kehidupan, peradaaaban dan martabat manusia

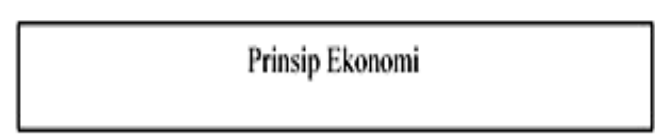

HKI merupakan satu bentuk kekayaan bagi pemiliknya. Dari pemilikan tersebut seseorang akan mendapatkan keuntungan.

\section{Prinsip Sosial}

Hak apapun yang diberikan oleh hukum yang diberikan kepada perseorangan atau persekutuan atau kesatuan lainnya juga untuk kepentingan seluruh masyarakat terpenuhi.

Selainprinsip-prinsip dasar mengapa perlu adanya perlindungan terhadap HKI, terdapat pula teori perlindungan HKI sebagaimana diungkapkan oleh Robert M. Sherwood, sebagai berikut: ${ }^{14}$

a. Teori reward (Reward Theory)

Teori reward mengatakan bahwa pencipta atau penemu yang akan diberikan perlindungan perlu dierika penghargaan atas usaha atau upaya tersebut. Ada

\footnotetext{
${ }^{13}$ Kholis Roisah, Op. Cit., hal. 26

${ }^{14}$ Robert M. Sherwood, Intellectual Property and Economic Development, Boulder Westview Press, 1990 lihat juga dalam Kholis Roisah,. Op.Cit..hal. 27-28
} 
terkandung semacam pengertian perihal penghargaan masyarakat atas usaha seseorang, suatu pengakuan atas keberhasilannya.

b. TeoriRecovery (Recovery Theory)

Teori Recovery mengatakan, mungkin tanpa suatu penilaian yang mendalam, bahwa penemu atau pencipta atau pendesain yang telah membuang waktu, biaya serta tenaga untuk menghasilkan karya intelektualnya perlu diberikan semacam kesempatan untuk meraih kembali apa yang telah dikeluarkannya.

c. Teori Insentif (Incentive Theory)

Teori Incentive mengatakan bahwa insentif bermanfaat untuk menarik upaya dan dana bagi pelaksanaan dan pengembangan kreativitas penemuan dan semangat untuk menghasilkan penemuan baru.

d. Public Benefit Theory

Public Benefit Theory, menyatakan dasar pemberian perlindungan hak atas kekayaan intelektual, yaitu untuk pengembangan ekonomi.

e. Risk Theory

Risk Theory menyatakan bahwa kekayaan intelektual merupakan hasil dari suatu penelitian yang mengandung resiko yang dapat memungkinkan orang lain yang terlebih dahulu menemukan cara tersebut atau memperbaikinya, sehingga wajar untuk memberikan perlindungan hukum terhadap upaya atau kegiatan yang mengandung resiko tersebut.

f. Economic Growth Stimulus Theory

Teori ini mengakui perlindungan atas HKI merupakan alat pembangunan ekonomi. Pembangunan ekonomi adalah keseluruhan tujuan dibangunnya sistem perlindungan atau HKI yang efektif.

Perlindungan HKI pada penerapannya di setiap negara yang satu dengan negara yang lainnya berbeda, karena dipengaruhi oleh sistem hukum, politik, budaya dan landasan filosofisnya yang berbeda-beda di masing-masing negara. Sistem perlindungan hukum HKI harus menjamin keseimbangan kepentingan pemegang hak dan kepentingan masyarakat umum. Kedua kepentingan tersebut merupakan dua sisi mata uang yang harus sama dipertimbangkan dalam konteks perlindungan HKI. 


\section{Perlindungan Hukum HKI Melalui Mekanisme Cross Border Measure}

Perlindungan hukum terhadap HKI mengalami perkembangan yang sangat pesat dalam tatanan internasional dan bahkan menjadi salah satu isu pada era globalisasi dan liberalisasi sekarang ini. Khususnya sejak menjadi salah satu agenda di dalam perundingan Putaran Uruguay atau Uruguay Round yang berlangsung dari tahun 1986 sampai 1994. Perundingan yang melahirkan World Trade Organization (WTO) atau Organisasi Perdagangan Dunia dan juga disepakatinya perjanjian internasional tentang Aspek-aspek Hak kekayaan Intelektual Terkait Perdagangan (Trade Related Aspects of Intellectual Property Rights-TRIPs Agreement).

Penegakan hak kekayaan intelektual terutama dalam lingkup ekspor dan impor (border enforcement) muncul sebagai salah satu isu penting selama proses negosiasi dan penyusunan TRIPs Agreement. Isu yang timbul selama perundingan tersebut yaitu berkaitan dengan pengaturan untuk menyeimbangkan antara kepentingan pemegang hak dan pihak importir. ${ }^{15}$

Sesuai dengan Undang-Undang Nomor 10 Tahun 1995 tentangKepabeanan sebagaimana telah diubah dengan Undang-Undang Nomor 17Tahun 2006, Direktorat Jenderal Bea dan Cukai diberikan kewenanganuntuk melakukan pengawasan dugaan pelanggaran Hak Atas KekayaanIntelektual terhadap lalu lintas barang impor maupun ekspor.Kewenangan ini sebenarnya merupakan pengejawantahan amanat dariWorld Trade Organization (WTO) Trade Related Aspects of Intellectual Property Rights (TRIPS) terutama bagian yang berkaitan denganpengawasan di perbatasan (border measures). Jika diperhatikan denganbaik, maka sebenarnya kewenangan yang diberikan kepada DirektoratJenderal Bea dan Cukai tersebut adalah sesuai dengan yang disarankan oleh TRIPs. Namun demikian patut untuk dicatat bahwa dalam beberapahal tertentu kewenangan yang diberikan kepada Direktorat Jenderal Beadan Cukai bahkan lebih progresif dibandingkan dengan rekomendasiTRIPs, misalnya dalam hal pengawasan terhadap ekspor.

\footnotetext{
${ }^{15}$ Aditya Gupta, Border Enforcement of Intellectual Property Rights in India: In Recent Developments, Trade, Law and Development Journal Vol. 1 Issue 2, 2009, halaman 262
} 
Kewenangan penegakan hukum HKI di perbatasan sebagaimana tertuang dalam TRIPs Agreement Section 4 Special Requirements Related To Border Measures Article 51 Suspension of Release by Customs Authorities, yang menyatakan:

\begin{abstract}
Members shall, in conformity with the provisions set out below, adopt procedures to enable a right holder, who has valid grounds for suspecting that the importation of counterfeit trademark or pirated copyright goods may take place, to lodge an application in writing with competent authorities, administrative or judicial, for the suspension by the customs authorities of the release into free circulation of such goods. Members may enable such an application to be made in respect of goods which involve other infringements of intellectual property rights, provided that the requirements of this Section are met. Members may also provide for corresponding procedures concerning the suspension by the customs authorities of the release of infringing goods destined for exportation from their territories.
\end{abstract}

Berdasarkan Article 51, pada prinsipnya memerintahkan setiap negara anggota untuk menerapkan prosedur yang memungkinkan pemegang hak/pemilik hak, yang memiliki bukti yang cukup atau alasan yang sah atas dugaan impor barang palsu (merek palsu) ${ }^{16}$ atau hak cipta bajakan ${ }^{17}$, mengajukan permohonan secara tertulis kepada otoritas yang berwenang, baik secara administratif atau yudisial, untuk melakukan penangguhan/pelepasan barang ke peredaran bebas melalui otoritas kepabeanan. Setiap negara anggota juga dapat mengizinkan permohonan yang sama sehubungan dengan pelanggaran HKI lainnya (selain merek dan hak cipta), sesuai dengan syarat-syarat yang diperlukan. Negara anggota juga dapat memberikan prosedur penangguhan pelepasan barang ekspor yang diduga melanggar HKI oleh pihak otoritas kepabeanan.

\footnotetext{
16"counterfeit trademark goods" shall mean any goods, including packaging, bearing without authorizationa trademark which is identical to the trademark validly registered in respect of such goods, or which cannotbe distinguished in its essential aspects from such a trademark, and which thereby infringes the rightsof the owner of the trademark in question under the law of the country of importation (TRIPs Agreement Article 51);

17"pirated copyright goods" shall mean any goods which are copies made without the consent of the rightholder or person duly authorized by the right holder in the country of production and which are madedirectly or indirectly from an article where the making of that copy would have constituted an infringementof a copyright or a related right under the law of the country of importation (TRIPs Agreement Article 51).
} 
Dalam rangka mengatur secara teknis penegakan ketentuan TRIPs Agreementdan UU Kepabeanan terkait cross border measure, Pemerintah telah menerbitkan Peraturan Pemerintah Nomor 20 Tahun 2017 tentang Pengendalian Impor Atau Ekspor Barang Yang Diduga Merupakan Atau Berasal Dari Hasil Pelanggaran Hak Kekayaan Intelektual (PP HKI). Pada dasarnya, Peraturan Pemerintah ini berisi penjabaran atasacuan dasar mekanisme pengawasan Hak Atas Kekayaan Intelektual olehDJBC sebagaimana diatur dalam Undang-Undang Kepabeanan.

Disamping itu, Peraturan Pemerintah ini juga mengenalkan hal baru yaitumekanisme perekaman HKI (recordation) kepada Direktorat Jenderal Beadan Cukai (DJBC). Penting untuk digarisbawahi bahwa mekanisme perekaman ini sama sekali tidak menggantikan mekanisme pendaftaran HKI kepadaDirektorat Jenderal Kekayaan Intelektual Kementerian Hukum dan HakAsasi Manusia. Mekanisme perekaman ini hanya bertujuan untukmembantu Direktorat Jenderal Bea dan Cukai agar memiliki data yangcukup mengenai HKI yang ada, sehingga Direktorat Jenderal Bea dan Cukai dapat melakukan profiling dan targeting yang lebih efektif. Beberapa negara telah lama menerapkan mekanisme perekaman ini dandalam prakteknya ternyata sangat membantu institusi kepabeanan untukmenjalankan fungsi pengawasannya dengan lebih baik, diantaranya China, Thailand, Malaysia, Singapura dan Vietnam.

Pengendalian impor atau ekspor barang yang diduga merupakan hasil pelanggaran Hak Kekayaan Intelektual di Indonesia merupakan salah satuupaya untuk meningkatkan pertumbuhan ekonomi nasional dengan mendorongkegiatan impor atau ekspor berjalan sesuai praktik perdagangan yangberkeadilan (fair trade) dengan menjamin kepastian hukum atas barang-barangyang telah dilindungi oleh Hak Kekayaan Intelektual serta dilaksanakan denganberlandaskan semangat partisipasi aktif masyarakat (public awareness) dan kewajiban negara untuk melindungi Hak Kekayaan Intelektual.

Adapun mekanisme perlindungan HKI berdasarkan PP HKI melalui mekanisme cross border measure, dilakukan melalui 2 cara, yaitu melalui penegahan berdasarkan kewenangan jabatan Pejabat Bea dan Cukai (ex-officio) 
atau melaluipenangguhan berdasarkan perintah dari KetuaPengadilan Niaga (yudisial). Adapun jenis HKI yang dilindungi berdasarkan PP HKI adalah Merek, Hak Cipta dan Hak terkait, Paten dan Paten Sederhana, Desain Industri, Desain Tata Letak Sirkuit Terpadu, Varietas Tanaman dan Indikasi Geografis.

Secara sederhana, mekanisme perlindungan HKI melalui cross border measureberdasarkan PP HKI dapat digambarkan sebagai berikut:

Gambar 2

Skema Perlindungan HKI di Kawasan Pabean

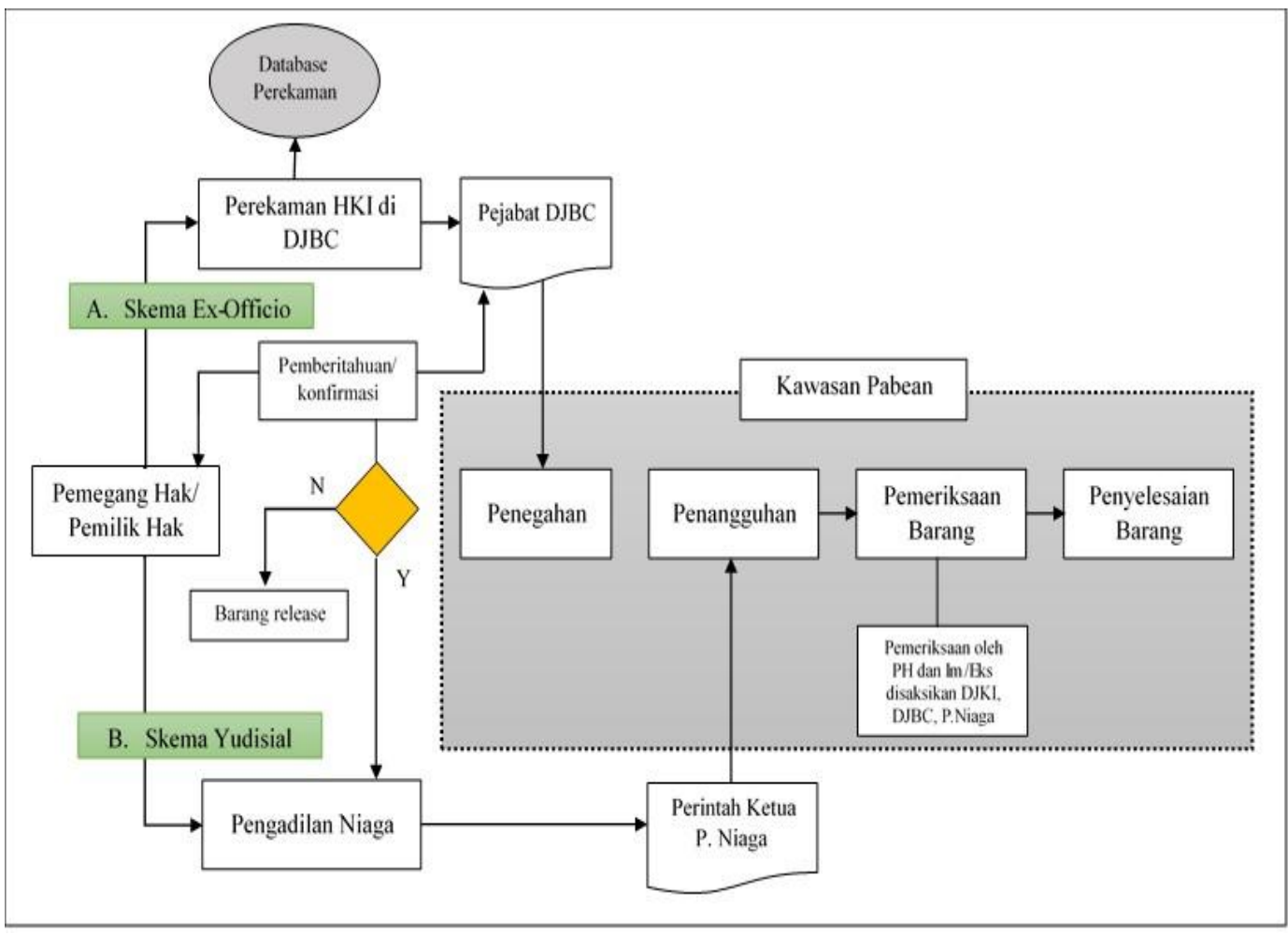

Mekanisme perlindungan HKI di Kawasan Pabean dapat diuraikan sebagai berikut:

1. Mekanisme Penangguhan melalui Skema Ex-Officio

Untuk memperoleh perlindungan HKI secara Ex-Officio, maka Pemilik Hak/Pemegang Hak terlebih dahulu melakukan permohonan perekaman kepada Pejabat Bea dan Cukai, dengan disertai:

a. Bukti kepemilikan hak;

b. Data mengenai ciri-ciri keaslian produk seperti merek, barang, nama dagang, tampilan produk, kemasan, rute distribusi, dan pemesaran, serta jumlah 
produk yang dipasarkan dalam suatu wilayah dalam halHak Kekayaan Intelektual berupa merek;

c. Data mengenai ciri-ciri atau spesifikasi karya cipta dibidang ilmu pengetahuan, seni, sastra, atau hak terkait yang diciptakan dalam halHak Kekayaan Intelektual berupa hak cipta; dan

d. Surat pernyataan pertanggungjawaban dari pemilik atau pemeganghak atas segala akibat yang timbul dari perekaman.

Dalam jangka waktu paling lama 30 hari sejak permohonan diterimapejabat bea cukai memberikan keputusan disetujui atau diterima, persetujuan pendataan pada sistem perekaman Direktorat Jendral Bea dan Cukai berlakuuntuk jangka waktu paling lama 1 (satu) tahun terhitung sejak tanggalpersetujuan dapat diperpanjang, dan dapat mencabut persetujuan berdasarkanhasil monitoring evaluasi dengan Menteri Keuangan. Dalam rangkapendataan pada sistem perekaman, Pejabat Bea dan Cukai melakukan validasidata mengenai HKI. Validasi data dapat dilakukan melaluikoordinasi dengan instansi atau pihak lain yang terkaitdalam rangka validasidata misalnya asosiasi pemegang atau pemilik HKI danorganisasi internasional yang terkait dengan perlindungan $\mathrm{HKI}$.

Pejabat Bea dan Cukai pada saat pemeriksaan pabean atau analisisintelijen berdasarkan pada informasi perekaman HKIpada Direktorat Jenderal Bea dan Cukai yang menemukan adanya barangimpor atau ekspor yang diduga merupakan atau berasal dari pelanggaran HakKekayaan Intelektual berupa merek atau hak cipta, harus memberitahukankepada pemilik atau pemegang hak berdasarkan bukti yang cukup. Terhadappemberitahuan tersebut pemilik atau pemegang hak harus memberikankonfirmasi untuk mengajukan permintaan perintah penangguhan dalam jangkawaktu paling lama 2 (dua) hari setelah tanggal pemberitahuan dengan syarat:

a. mempersiapkan persyaratan administrasi pengajuan permintaanperintah penangguhan kepada Ketua Pengadilan; 
b. menyerahkan jaminan biaya operasional kepada Pejabat Bea dan Cukai sebesar Rp.100.000.000.00 (seratus juta rupiah) dalam bentukjaminan bank atau jaminan dari perusahaan asuransi; dan

c. mengajukan permintaan penangguhan melalui permohonan kepada Ketua Pengadilan, dalam jangka waktu paling lama 4 (empat) harikerja sejak konfirmasi dari pemilik atau pemegang hak;

Pejabat Bea dan Cukai dapat memberikan ringkasan mengenai barangimpor atau ekspor yang diduga merupakan atau berasal dari hasil pelanggaranHak Kekayaan Intelektual berupa merek atau hak cipta untuk pemenuhanpersyaratan permintaan penangguhan melalui permohonan kepada KetuaPengadilan.Sebagai catatan, jaminan biaya operasional yang diserahkan kepada Pejabat Bea dan Cukai bukan merupakan jaminan yang terkait dengan nilai barang, akan tetapi jaminan yang akan digunakan dalam rangka handling cost di pelabuhan, seperti biaya pemeriksaan, biaya pembongkaran, biaya penimbunan dan biaya pengangkutan. ${ }^{18}$

2. Mekanisme Penangguhan melalui Skema Yudisial

Pemilik atau pemegang hak atau kuasanya dapat mengajukan permintaan penangguhan atas barang impor atau ekspor yang diduga merupakan atau berasal dari hasil pelanggaran Hak Kekayaan Intelektual, kepada KetuaPengadilan Niaga disertai:

a. bukti yang cukup mengenai adanya pelanggaran Hak KekayaanIntelektual yang bersangkutan;

b. bukti kepemilikan Hak Kekayaan Intelektual yang bersangkutan;

c. perincian dan keterangan yang jelas mengenai barang impor atauekspor yang dimintakan penengguhannya, agar dengan cepat dapat dikenali oleh Pejabat Bea dan Cukai; dan

d. Jaminan biaya operasional sebesar Rp.100.000.000.00 (seratus juta rupiah) dalam bentuk jaminan bank atau jaminan dari perusahaanasuransi kepada Pejabat Bea dan Cukai dalam jangka waktu palinglambat 2 (dua) hari kerja

\footnotetext{
${ }^{18}$ Penjelasan Pasal 7 ayat (5) Peraturan Pemerintah Nomor 20 Tahun 2017 tentang Pengendalian Impor Atau Ekspor Barang Yang Diduga Merupakan Atau Berasal Dari Hasil Pelanggaran Hak Kekayaan Intelektual.
} 
sejak tanggal penetapan perintahPenangguhan diterima Pejabat Bea dan Cukai diajukan kepada KetuaPengadilan yang wilayah hukumnya meliputi Kawasan Pabeantempat kegiatan impor atau ekspor yang terdapat barang yang didugamerupakan atau berasal dari hasil pelanggaran Hak KekayaanIntelektual. Pengadilan mengabulkan atau menolak permohonantersebut dengan penetapan dalam jangka waktu paling lama 2 (dua)hari kerja setelah tanggal pendaftaran permohonan.

Pengadilan menyampaikan penetapan perintah Penangguhan kepada Pejabat Bea dan Cukai di tempat kegiatan impor atau ekspor yang didugamerupakan atau berasal dari hasil pelanggaran Hak Kekayaan Intelektualdalam jangka waktu paling lama 1 (satu) hari kerja setelah ditetapkan sesuaidengan Peraturan Mahkamah Agung No.4 Tahun 2012 tentang PenangguhanSementara.

Berdasarkan penetapan perintah penangguhan dengan penetapan pengadilan tersebut, Pejabat bea dan cukai harus:

a. memberitahukan secara tertulis kepada:

1) importir, eksportir, atau pemilik barang;

2) pemilik atau pemegang hak; dan

3) Direktorat Jenderal Kekayaan Intelektual,mengenai penetapan perintah Penangguhan dari Pengadilan; dan

b. melaksanakan Penangguhan sejak tanggal penetapan perintahPenangguhan diterima.

3. Pemeriksaan Fisik

Pemilik atau Pemegang Hak mengajukan permohonan jadwal pemeriksaan fisik barang impor atau ekspor kepada Pejabat Bea dan Cukaidalam jangka waktu paling lambat 2 (dua) hari kerja sejak tanggal penetapanperintah Penangguhan diterima Pejabat Bea dan Cukai.Pemeriksaan fisik barang impor atau ekspor dilaksanakan berdasarkan jadwal yang telah ditentukan oleh Pejabat Bea dan Cukai. Pemeriksaan barangimpor atau ekspor dilakukan Pemilik atau Pemegang Hak secara bersama-samadengan:

a. Pejabat Bea dan Cukai; 
b. perwakilan dari Pengadilan;

c. perwakilan dari Direktorat Jenderal Kekayaan Intelektual; dan

d. importir/eksportir/pemilik barang atau kuasanya.

Apabila hal importir/eksportir/pemilik barang atau kuasanya tidak hadir,pemeriksaan tetap dilakukan. Pejabat Bea dan Cukai melaksanakanPenangguhan dalam jangka waktu paling lama 10 (sepuluh) hari kerja terhitungsejak surat perintah atau penetapan Penangguhan diterima dan pemilik atauPemegang Hak dapat mengajukan permohonan perpanjangan Penangguhansebanyak 1 (satu) kali untuk jangka waktu paling lama 10 (sepuluh) hari kerjakepada Ketua Pengadilan, Perpanjangan Penangguhan disertai denganperpanjangan jaminan.

4. Pengakhiran Penangguhan

Pengakhiran penangguhan dapat dilakukan oleh Pejabat Bea dan Cukaidalam hal:

a. berakhirnya masa Penangguhan;

b. berakhirnya masa perpanjangan Penangguhan;

c. terdapat perintah penetapan mengakhiri Penangguhan dariPengadilan untuk mengakhiri Penangguhan; atau

d. terdapat tindakan hukum atau tindakan lain atas adanya dugaanpelanggaran Hak Kekayaan Intelektual.

Dalam keadaan tertentu importir, eksportir atau pemilik barang dapat mengajukan permintaan kepada Ketua Pengadilan untuk memerintahkansecara tertulis kepada Pejabat Bea dan Cukai agar mengakhiri Penangguhan.Permintaan pengakhiran penangguhan disertai dengan menyerahkan jaminanRp.100.000.000.00 (seratus juta rupiah).Dalam hal Penangguhan berakhir terhadap barang yang ditangguhkandapat dilakukan antara lain:

a. diselesaikan sesuai dengan prosedur impor atau ekspor berdasarkanketentuan peraturan perundang-undangan dibidang kepabeanan;

b. diserahkan kepada penyidik dalam hal dilakukan tindakan hukum berdasarkan ketentuan pidana; 
c. diserah terimakan kepada juru sita Pengadilan dalam hal Pemilik atau Pemegang Hak mengajukan gugatan dan/atau permohonan sita jaminan atas barang yang ditangguhkan; atau

d. penyelesaian sengketa di luar pengadilan sesuai dengan perundang-undangan.

Jaminan biaya operasional dicairkan untuk menanggung segala biayayang timbul akibat adanya Penegahan dan/atau Penangguhan, terhadapkekurangannya ditagihkan kepada Pemilik atau Pemegang Hak dan apabilajaminan biaya operasional melebihi biaya yang timbul akibat adanyaPenegahan dan/atau Penangguhan, terhadap kelebihannya dikembalikankepada pemilik atau pemegang hak. Ketentuan lebih lanjut mengenai tata carapencairan, penagihan, dan pengembalian jaminan biaya operasional diatur dengan Peraturan Menteri Keuangan.

5. Pengecualian Penangguhan

Ketentuan Penangguhan tidak diberlakukan terhadap barang bawaanpenumpang, awak sarana pengangkut, pelintas batas atau barang kirimanmelalui pos atau jasa titipan yang tidak dimaksudkan untuk tujuan komersial. Ketentuan lebih lanjut mengenai kriteria tujuan komersial diatur denganPeraturan Menteri Keuangan.

Ketentuan Penangguhan tidak diberlakukan terhadap barang imporangkut lanjut atau angkut terus dengan tujuan luar Daerah Pabean yang didugamerupakan atau berasal dari pelanggaran Hak Kekayaan Intelektual. Pengendalian barang impor angkut lanjut atau angkut terus yang diduga hasilpelanggaran Hak Kekayaan Intelektual dilakukan oleh Pejabat Bea dan Cukaidengan mengirimkan surat pemberitahuan kepada pejabat pabean di Negaratujuan pengangkutan selanjutnya.

\section{Penutup}

Berdasarkan uraian yang telah mekanisme perlindungan HKI melalui cross border measure di atas, penulis memiliki kesimpulan antara lain:

1. Perlindungan terhadap HKI sebagai karya intelektual manusia memiliki arti penting dalam masyarakat nasional maupun internasional. Negara memiliki 
peran dalam menyeimbangkan antara kepentingan pemilik hak/pemegang hak dengan kepentingan masyarakat. Dampak perlindungan terhadap HKI tidak hanya dalam rangka perlindungan ekonomi saja, akan tetapi juga meliputi faktor kesehatan dan keselamatan bagi masyarakat untuk memperoleh jaminan barang-barang yang aman dikonsumsi/digunakan seperti obat-obatan dan sparepart.

2. Perlindungan HKI melalui mekanisme cross border measure dapat dilakukan melalui skema penegahan berdasarkan kewenangan jabatan Pejabat Bea dan Cukai (ex-officio) atau melalui penangguhan berdasarkan perintah dari KetuaPengadilan Niaga (yudisial). Skema ex-officiotentunya akan lebih efektif, mengingat adanya peran aktif dari pihak Direktorat Jenderal Bea dan Cukai dalam pengawasan barang impor atau ekspor yang terkait dengan pelanggaran HKI. 


\section{Daftar Pustaka}

CitaCitrawinda Priapantja,2003,Hak Kekayaan Intelektual Tantangan Masa Depan, Cet. 1, Jakarta: Badan Penerbit Fakultas Hukum Universitas Indonesia.

Direktorat Jenderal Hak Kekayaan Intelektual Kementerian Hukum dan HAM RI, 2013, Buku Panduan Hak Kekayaan Intelektual, Tangerang: 2013.

MuhamadDjumhana dan R. Djubaedillah, 2014, Hak Milik Intelektual (sejarah, teori dan praktiknya di Indonesia), Bandung: PT. Citra Aditya Bakti.

AdityaGupta,2009,Border Enforcement of Intellectual Property Rights in India: In Recent Developments, Trade, Law and Development Journal Vol. 1 Issue 2, 2009.

SunaryatiHartono,1982, Hukum Ekonomi Pembangunan Indonesia, Bandung: Bina Cipta.

BambangKesowo,1993, Posisi dan Arti Penting HKI Dalam Perdagangan Internasional, Jakarta:1993

Organization of Economic Cooperation and Development(OECD), 2016, Trade in Counterfeit and Pirated Goods: Mapping the Economic Impact, Paris: OECD Publishing.

Peraturan Pemerintah Nomor 20 Tahun 2017 tentang Pengendalian Impor Atau Ekspor Barang Yang Diduga Merupakan Atau Berasal Dari Hasil Pelanggaran Hak Kekayaan Intelektual.

KholisRoisah, 2015. Konsep Hukum Hak Kekayaan Intelektual: sejarah, pengertian dan filosofi pengakuan HKI dari masa ke masa, Malang: Setara Press.

BudiSantoso,2008, Pengantar Hak Kekayaan Intelektual, Semarang: Pustaka Magister.

Robert M.Sherwood,1990, Intellectual Property and Economic Development, New York: Boulder Westview Press.

SoerjonoSoekanto,2010, Pengantar Penelitian Hukum, Jakarta: UI-Press. 
AdrianSutedi, 2012, Aspek Hukum Kepabeanan Indonesia, Jakarta: Sinar Grafika. Undang-Undang Nomor 10 Tahun 1995 tentang Kepabeanan Sebagaimana Telah Diubah Dengan Undang-Undang Nomor 17 Tahun 2006. 